\title{
Circular Economy: a Comparison Between the Case of Singapore and France
}

\author{
Erfan Rezvani Ghomi ${ }^{1} \cdot$ Fatemeh Khosravi $^{1} \cdot$ Mohammad Amin Tahavori $^{2} \cdot$ Seeram Ramakrishna $^{1}$
}

Received: 12 November 2020 / Revised: 22 December 2020 / Accepted: 25 December 2020 / Published online: 11 January 2021

(C) The Author(s), under exclusive licence to Springer Nature Singapore Pte Ltd. part of Springer Nature 2021

\begin{abstract}
Nowadays, due to the continuous developments in economies, various dilemmas are emerging, including energy demand, waste management, and greenhouse gas emissions (GHE). A promising approach to address these issues is a transition toward a circular economy (CE), and one of its successful approaches is the waste-to-energy (WTE). By exploiting WTE, there will be less demand for raw materials and resources. In this study, two developed countries, including France and Singapore, are evaluated based on their CE transition using the WTE method. Both countries are developing rapidly in terms of a successful CE. Reducing landfills as the major problem in Singapore is one of the most vital plans in their CE project. The planned target in Singapore is reducing landfill by $30 \%$ by 2030 . Furthermore, Singapore aims for reaching a $70 \%$ recycling rate by 2050 . On the other hand, the CE in France includes more comprehensive laws in four different sectors, such as production, consumption, waste management, and mobilizing actors. It is planned that by 2025 , the recycling rate in France will reach $100 \%$. A roadmap toward building a CE cannot be succeeded unless some practical strategies are developed for overcoming the encountered obstacles. The roadmap of both countries shows a specific milestone to reach a better CE, cleaner environment, and less use of natural resources. Most of the Singapore sustainable plans are planned to be caught by 2030, while France is trying to complete them by 2025. It should be noted that due to the current pandemic situation caused by COVID-19, there are some issues in implementing the obligations and plans thoroughly.
\end{abstract}

Keywords Circular economy $\cdot$ Zero waste $\cdot$ Sustainable development $\cdot$ Singapore $\cdot$ France

\section{Introduction}

Natural resources and raw materials are the physical foundation of the world, which are the initial requirements for the growing economy. However, most of these valuable resources eventually end up as waste materials. Hence, global waste management should be implemented to develop an economic material use model to stop the waste of materials and consuming them wisely (Baldé et al. 2017; Rezvani Ghomi et al.

Erfan Rezvani Ghomi

erfanrezvani@u.nus.edu

Seeram Ramakrishna

seeram@nus.edu.sg

1 Center for Nanofibers and Nanotechnology, Department of Mechanical Engineering, Faculty of Engineering, National University of Singapore, Singapore 117581, Singapore

2 Department of Energy, Politecnico di Milano, Via Lambruschini 4, 21056 Milan, Italy 2020b; Shanmugam et al. 2020; Telega and Telega 2020). Developing a circular economy system (CES) provides sufficient management in handling the life cycle of raw materials and enables economic development which is lucrative for society, businesses, and the environment. Besides, a CES aims to end up the consumerism culture by keeping products, components, and materials at their highest utility and value. In other words, CES is based on repairing and recycling culture and produces energy from renewable sources, whereas in a linear economy, energy is achieved from finite resources (Invernizzi et al. 2020; MacArthur 2013). Figure 1 can help us to distinguish the differences between $\mathrm{CE}$ and linear economy (Heidrich et al. 2016).

Transition to a circular approach in the production systems leads to reducing the consumption of raw materials (Rezvani Ghomi et al. 2020a), and as a result, greenhouse gas emission (GHE) and use of natural resources could be controlled within the specific territory. As an example, in France, when plastic bottles are produced from recycled materials, there will be a $70 \%$ decrease in $\mathrm{CO}_{2}$ emission in the production process comparing to using virgin raw materials (de Sousa Jabbour et al. 2018). 
Fig. 1 Comparison between circular and linear economy

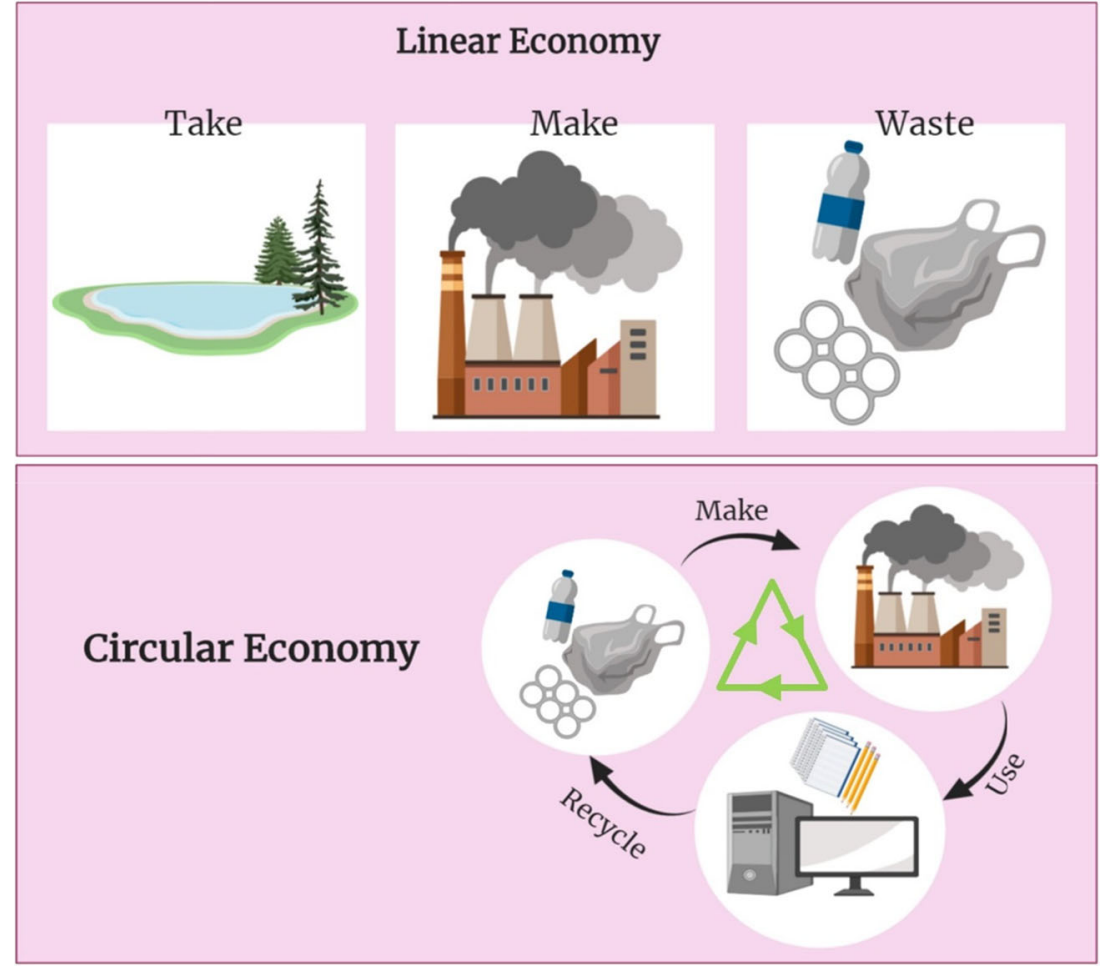

Establishing a circular economy (CE) is a must toward facing growing waste obstacles which is essential for both supply security and environmental perspectives, and it will lead to a sustainable and competitive economy.

The purposes of a CE is (Domenech and Bahn-Walkowiak 2019):

I. Maximizing the circulation of the valuable materials within the industry;

II. Modifying the consumption customs and pay attention to recycles materials rather than raw materials;

III. Lowering waste generation by reuse option and decline in producing hazardous components in the environment.

To solve the growing energy demand, waste problems, and GHE globally, a viable method is developing a waste-toenergy (WTE) strategy. Indeed, turning waste into energy is a viable tool for a $\mathrm{CE}$ to maintaining the resources, product values, and services (Malinauskaite et al. 2017). Moreover, several state-of-the-art WTE strategies being used currently are combustion, gasification, and anaerobic digestion (Pan et al. 2015). Energy recovery from municipal solid wastes (MSW) can be established by using WTE technologies (Dong et al. 2018). It should be noted that the basis of the CES is advantageous for both economic and environmentally friendly profits (Tukker 2015). In general, WTE systems consist of four different categories based on biotechnology utilization including physical, thermal, chemical, and biological (Pan et al. 2015). Therefore, different methods have a common feature; in all of them, waste converts directly to energy such as heat or electricity or in the form of biofuel for other purposes such as transportation. In addition, other methods including bio-heating (Gómez-Cortés et al. 2009), incineration (Pavlas et al. 2011), and co-digestion (PagésDíaz et al. 2014), have also been investigated for WTE technologies.

The relationship between the CES and WTE supply chain and their impact on the environment is shown in Fig. 2. As can be seen in Fig. 2, both CE and WTE are promising solutions for resolving environmental and economic issues and addressing the resource scarcity crisis. In some studies, it is mentioned that the CES is based on 3R principles including Reduce, Reuse, and Recycle (Geng et al. 2012), while later, 5R principles are encouraged by adding Recovery and Reclamation to the $3 \mathrm{R}$ principles (Pan et al. 2015). Nowadays, a 10R approach is suggested as the state-of-the-art used for Singapore zero waste masterplan with five more additional principles including Refuse, Refurbish, Remanufacture, Repurpose, and Re-mine (Liu et al. 2018).

As WTE technologies are among the most promising approaches [9] for energy generation from MSW, many European countries are implementing these strategies to overcome their waste problems. Among European countries, France is well-known for European leadership in WTE technologies. In addition, this country benefits from the experienced French policymakers who can provide a role model in climate-related matters in CES (Arbulú et al. 2017). Since environmental impacts in WTE technologies are a crucial 


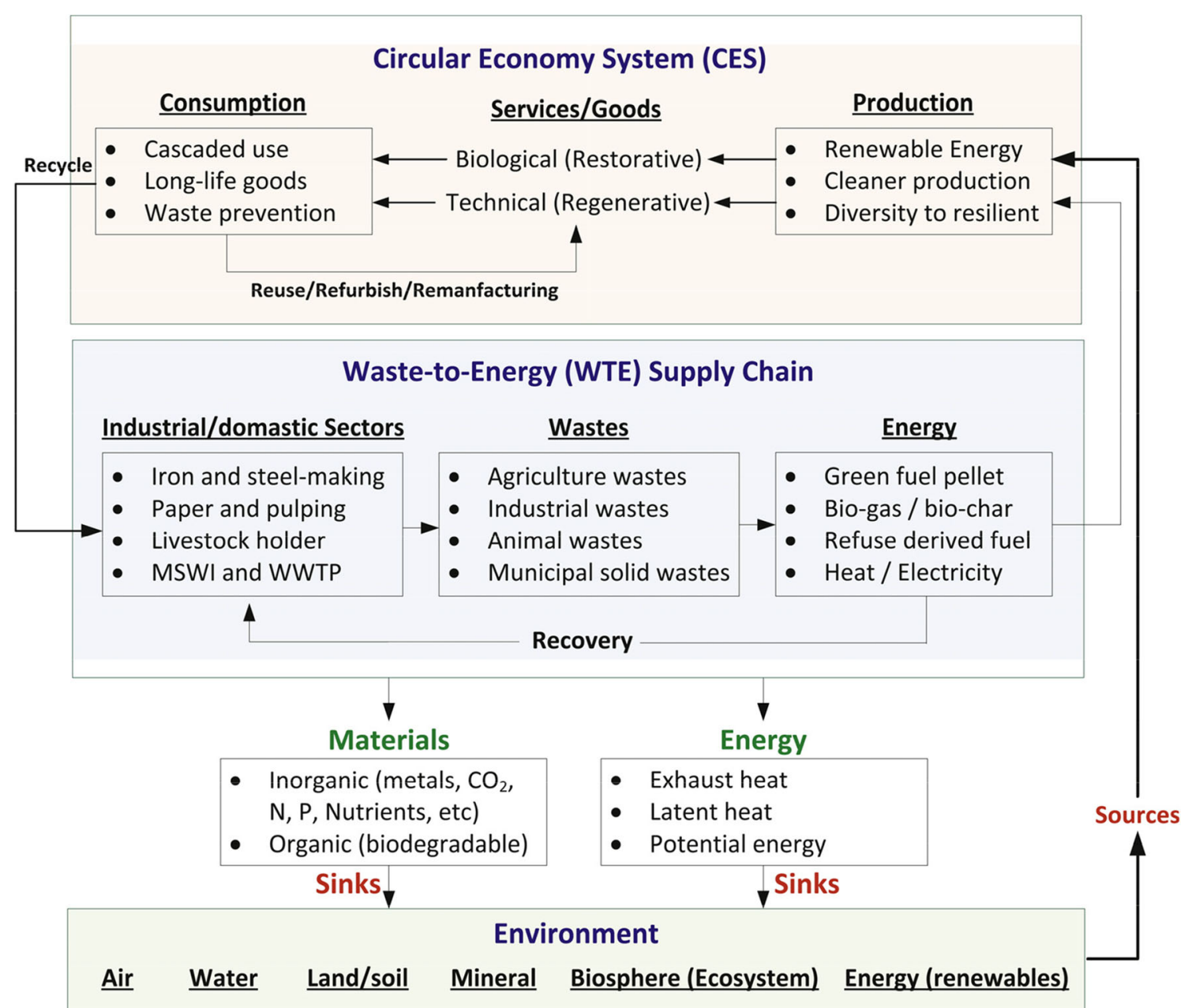

Fig. 2 The relationship between CE and WTE supply chain, and their impacts on the environment (Pan et al. 2015)

challenge, policymakers in France have utilized life cycle assessment (LCA) approaches for the overall environmental performance of the waste management technics (Ayodele et al. 2017). The implemented WTE technologies in France is incineration; therefore, the number of incineration plants in France is more than any other EU country (Dong et al. 2018). However, regarding the sustainability of this approach and its environmental impacts, the policy actors made decisions for sustainable development strategies such as setting tax for incineration plants and preventing or recycling wastes. As a consequence, the number of incineration plants from 2001 to 2016 had been decreased from 140 to 131 (Arbulú et al. 2017). In France, besides increasing the rate of recycling (Woodard 2021), the focus of WTE's new technologies is developing smaller incineration plants with high energy recovery in densely populated areas (Woodard 2021).

The start of the Singapore waste management system goes back to the 1960s when the housing development guard prepared shelters for the inhabitants (Deborah et al. 2018). The approach for waste management in Singapore was incineration, and its waste collection and disposal system was efficient enough at that time (Deborah et al. 2018). Their first incineration plant, Tuas incineration plant, was completed in 1986 with $1700 \mathrm{t}$ per day capacity. Besides this plant, there are three other plants in which unrecyclable wastes are incinerated (Fujii and Rohan 2019) and all of them send their produced ash to the Samakau landfill. The current WTE approach in Singapore, incineration, is not suitable at the current waste generation rate and hence, disposal of the ash product in this strategy itself is a significant issue. Lack of space in Samakau Landfill is a straightforward observation for the inefficiency of this WTE technology (Van Rensburg et al. 2020). Singapore plans are to establish a $\mathrm{CE}$ in which it can increase the incineration plants' capacity along with more recycling and minimizing carbon emissions from incineration (Siow and Lee 2020).

This article is a case study for the CE in France and Singapore based on WTE technologies and provides comparisons between them in terms of development in CES. Firstly, the main human-made problems stemming from wrong throwaway cultural habits are described. Secondly, a transition from a linear economy toward a CE is explained, and, France and Singapore are evaluated in terms of CES. In the last section, the challenges and strategies for the future of $\mathrm{CE}$ are mentioned. 
While many studies have been conducted to assess the impacts of approaching a CES based on WTE technologies in Singapore, the lack of a comparative analysis between Singapore and other pioneer countries in this field such as France is still missing (Kerdlap et al. 2019; Kuznetsova et al. 2019). Hence, it is an essential step in figuring out the optimum transition pathway for the specific context considering the experiences of the role model examples. Moreover, the COVID19 pandemic has shown a great level of vulnerability of such plans for unpredicted events. As a result, a part of the discussion is dedicated to assessing the impacts of such issues toward the CES transition plans and the ways that can be used to address them with a specific focus on the COVID-19 pandemics.

\section{Our Throwaway Culture}

Our planet is our second house which directly affects our lives. One of the basic problems regarding waste management stem from the wrong cultural habits in each society. The correct waste separation and disposing of harmful trash in the environment are significant cultural problems. The current throwaway culture is defined as "take, make, disposal" which is based on the linear economy as shown in Fig. 1 (Heidrich et al. 2016). This linear way of consumption is no longer viable due to the rapid growth of population and economy and requires to alter to a circular model (Jahani et al. 2019). To obtain a more efficient waste management system, it is required to ensure the efficient consumption of materials at all stages of their lifecycles. This life cycle is divided into two categories: before usage (extraction and production) and after usage (disposal and recycling) (Du et al. 2020). To this aim, a waste hierarchy is needed which shows the waste management options based on the desirable priority. The important steps of the new waste hierarchy are depicted in Fig. 3.

\section{CE in Singapore}

Historically, before the definition of the CE concept, Singapore has reduced its wastes by incineration. The first WTE incineration plant was built in 1979 with a cost of 130 million dollars. Incineration was a popular solution for the waste problem in Singapore due to up to $90 \%$ reduction in the waste volume (Hannon and Zaman 2018). However, there are environmental issues due to incineration which requires new actions. The Semakau area with an area of 350 ha was opened for landfilling of 200,000 $t$ of solid waste and incineration ash in Singapore from 1999. This landfill was the first man-made offshore landfill. However, the environmental threats in Samakau have affected about 700 species of animals and plants (ZERO WASTE MASTERPLAN n.d.). In addition to the environmental issues, Samakau is the only place left for landfilling in Singapore (ZERO WASTE MASTERPLAN). Due to space limitation in Samakau landfill until 2035 and the pollution threat for animal and plant species, Singapore is forced to reduce the amount of waste sent to Samakau (ZERO WASTE MASTERPLAN). Hence, the time of flourishing a CE in Singapore was started.

The year 2019 is regarded as the beginning of the zero waste masterplan in Singapore by decreasing the consumption rate through reusing and recycling (FrancoGarcía et al. 2019). The focus of the zero waste masterplan was defined on electronic, packaging, and food waste in 2019. In this plan, the $10 \mathrm{R}$ approach was used (Liu et al. 2018) and the target is reducing landfills by $30 \%$ by 2030 . Therefore, the lifespan of the Samakau landfill can go beyond 2035, which was estimated until 2030 before the implementation of the masterplan (Chan 2016). In addition, there are new obligations for the collection and treatment of electronic and food wastes in Singapore (Abidin 2020) as shown below:

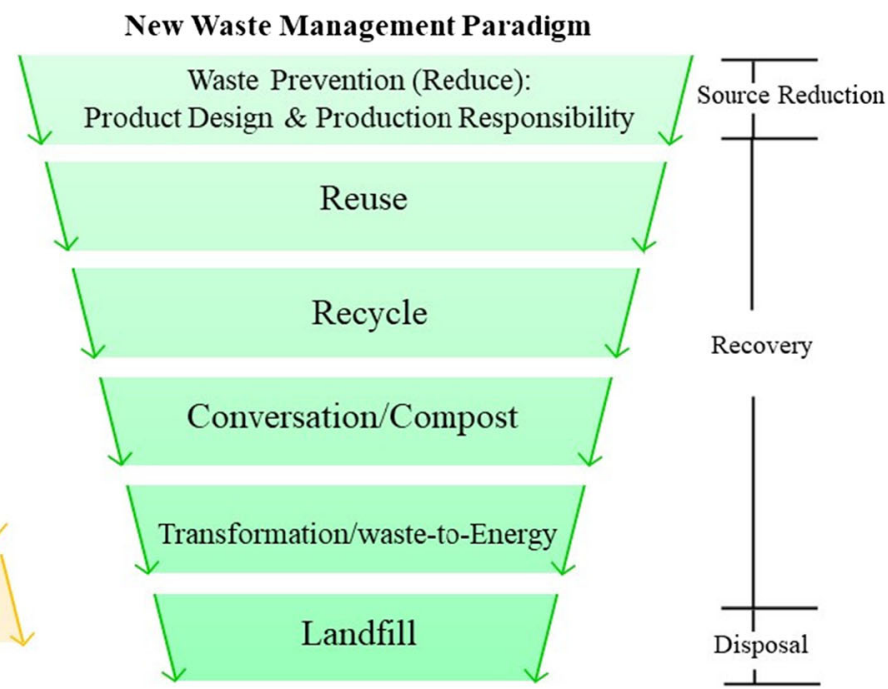

Fig. 3 Comparison between traditional and new waste hierarchy 
1. Mandatory packaging by 2020

2. Expanding the responsibility of producers for electronic waste by 2021

3. Mandatory treatment in food waste by 2024

4. Increasing the producer responsibilities for packaging, especially plastics by 2025 (Chan 2016)

By means of these obligations within 50 years, Singapore can reach the target of $70 \%$ recycling, and landfilling and incineration can be decreased to a large proportion. Based on the represented information in Fig. 4, recycling in Singapore has increased from 54 to $58 \%$ from 2007 to 2010 , which is a slight improvement. In the same years, the incineration and landfilling of wastes have decreased at a slight amount from 42 to $40 \%$ and $3 \%$ to $2 \%$, respectively. However, waste management in Singapore has a target of $70 \%$ recycling within 50 years.

However, in the COVID-19 coronavirus pandemic, these obligations were not considered. Some studies present cases for waste management in future pandemics because in these cases, it is needed to ensure a safe waste management system (Sharma et al. 2020). For better waste management during the pandemic, numerous priorities should be investigated in different sectors as shown in Fig. 5. Respecting the disposing, it should be ensured to prevent virus spread based on up-to-date standards. Another concerning factor is about workers involved in the waste collection. Besides ensuring the safety of the workers, the government should provide them selfinsurance and health care services. Last but not the least, informing and educating people about waste generation and collection, and its impacts on the virus spreading. By obeying these principles, we can get through COVID-19 and other pandemics in the future.



Fig. 4 Recycling rate in 2007, 2008, 2009, 2010, and the target for 2050 (ZERO WASTE MASTERPLAN)
The efforts of Singapore in implementing CE in recent years are worthy of mention. As an example, this country seeks ways to produce jet fuel by 2022 (Mawhood et al. 2016). This fuel is made by converting waste materials such as liquefied waste plastic to renewable energy. Moreover, some other developments in treatment facilities such as transport infrastructure and industrial facilities, prepare Singapore for its zero waste and low-carbon emission strategies (FrancoGarcía et al. 2019).

The zero waste framework in Singapore is shown in Fig. 6. The most important factor to establish a CE in all of its aspects is financial aids (Lahsen et al. 2020). The Singapore zero waste program has two sections: legislation and policies from the government and zero waste incentives. Sustainable Singapore Blueprint and Resource Sustainable Bill are the policies toward the CE in Singapore. Resource Sustainable Bill policy was applied in 2019 for obligations about waste collection and their treatment (Steele et al. 2019). Besides, there are some incentives toward a $\mathrm{CE}$, such as government research grants. As an example, two million dollars is available for zero waste projects, and the National Environment Agency (NEA) practices to adopt a CE economy approach (Carrière et al. 2020).

\section{CE in France}

The early days of waste management in France goes back to the sixteenth century when king Francis I ordered the citizens to use a basket for collecting their waste (Ballouard et al. 2017). The years after that time until the nineteenth century, the collected waste went to the landfills without recycling. In the twentieth century, because of the technological development and population growth, a waste management program was developed by the Royal Act in 1992 (Hugo 14 juillet 1992). Due to the obligations of the Royal Art, the rate of waste storage in France decreased from $43 \%$ in the 2000s to $26 \%$ in 2013 (Qu et al. 2019). As shown in Fig. 7, organic recovery increased from 53 to $73 \%$ between 2000 to 2013, and also, incineration as a way of WTE technology increased in this period.

The CE in France is based on the targets of the Agenda 2030 Sustainable Development Goals (SDGs) (Belaud et al. 2019), and its aim is increasing waste valorization to $70 \%$ weight by 2020 and developing a CE through a Construction and Demolition $(C \& D)$ management for recycling and reusing. For improvement of the CE in France, several approaches have been implemented:

I. Supporting a new recycling business

II. Reducing taxes on recycled materials

III. A framework for preventing illegal material trafficking (Nguyen 2019) 


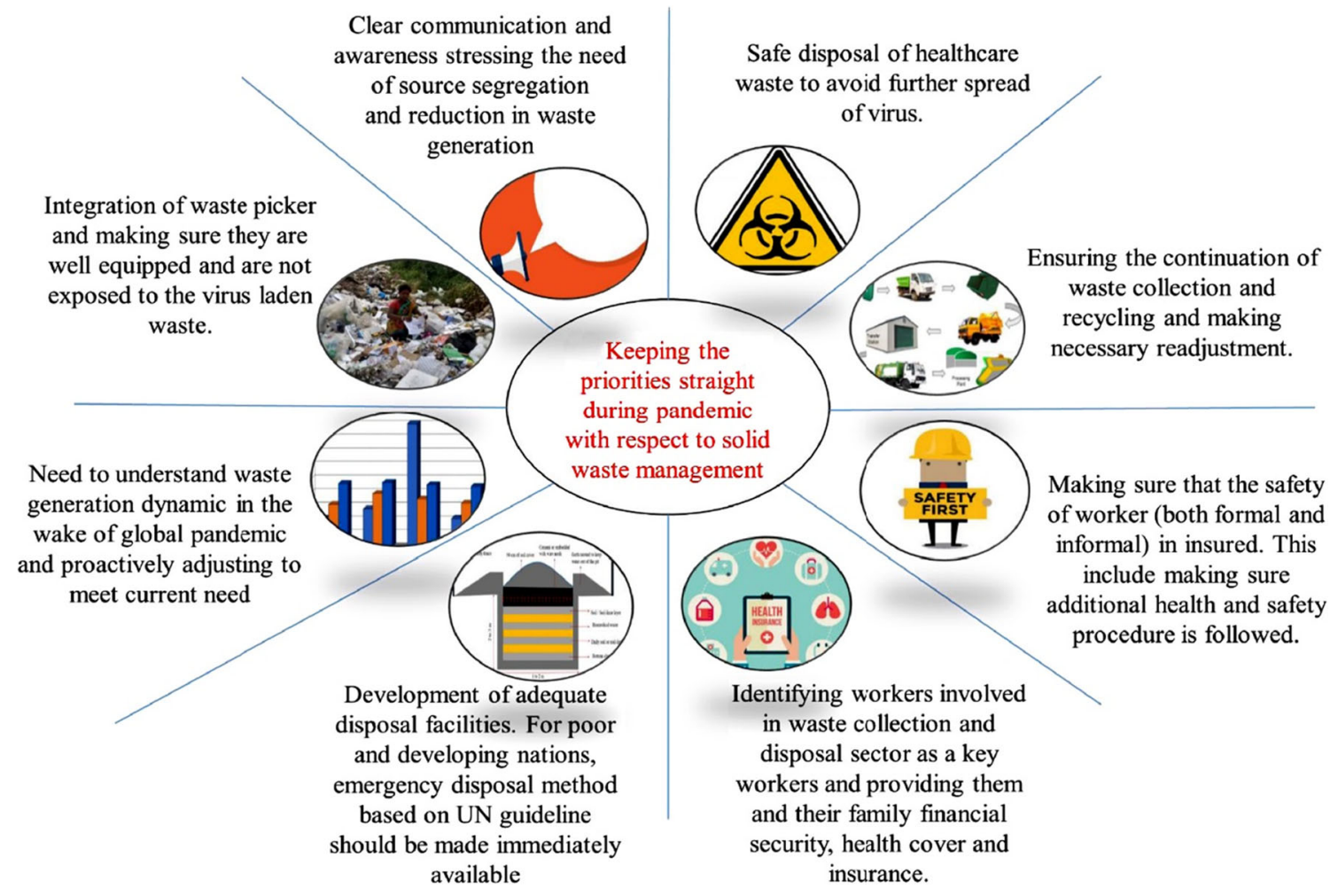

Fig. 5 Waste management system in future pandemics (Sharma et al. 2020)

Fig. 6 Singapore zero waste framework

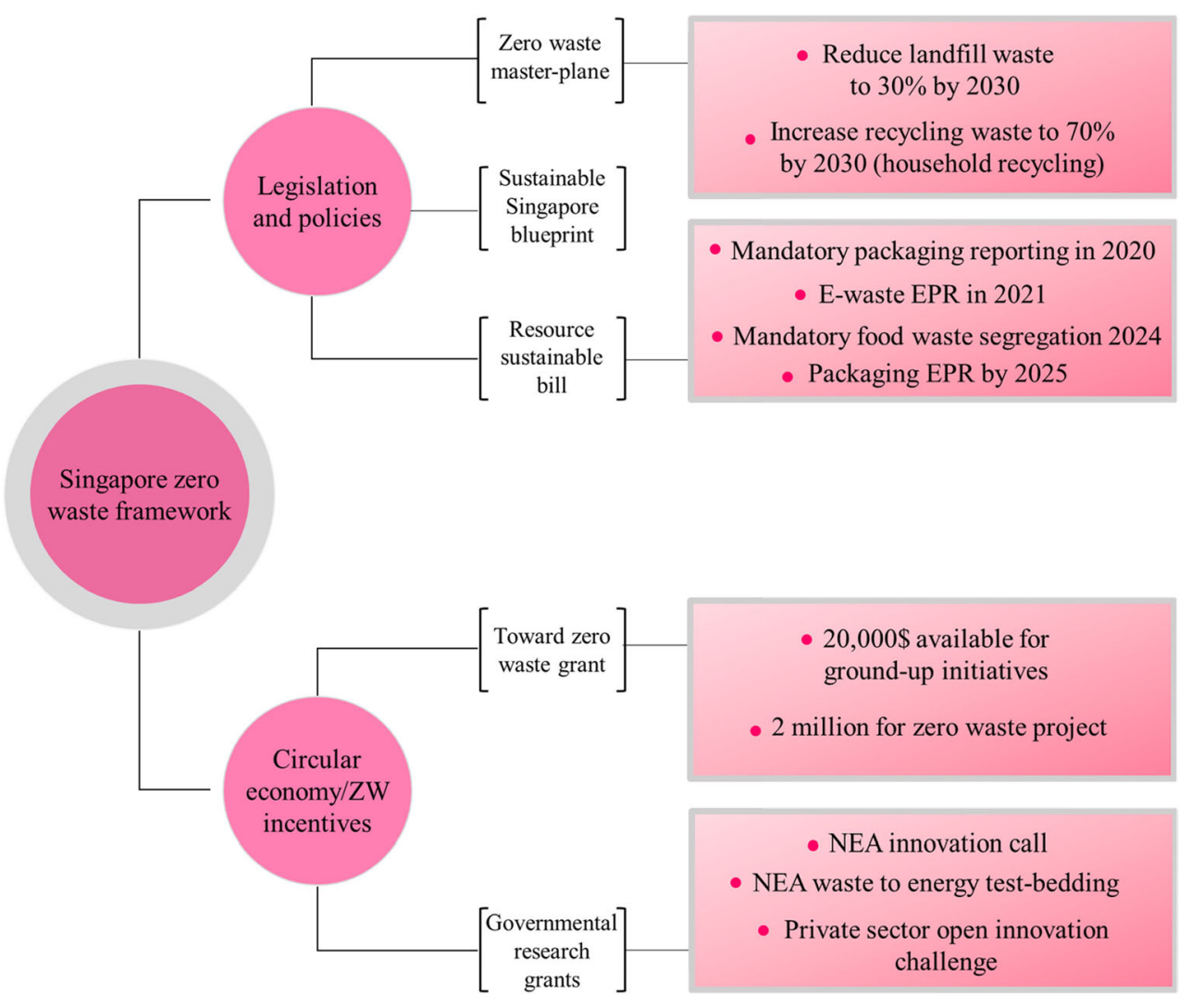


Fig. 7 Evolution of household waste treatment in France between 2000 and 2013 derived from Ademe (2016) (Nguyen 2019)

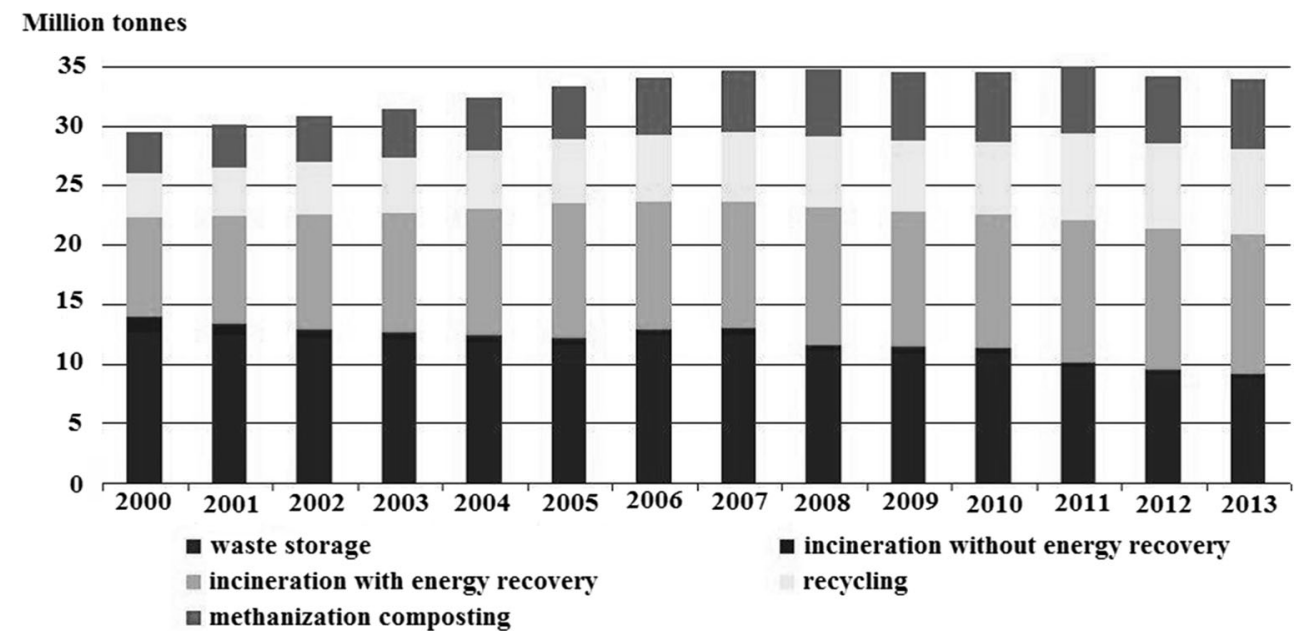

Field: hors deblais et gravats; metropolitan France and DOM

Sources: Ademe; SOeS
The CE framework in France was established on August 17, 2015, by the French parliament (Liszka and Walawender 2018) as shown in Fig. 8.

The patterns toward a CE in France have changed their consumption culture. $\mathrm{CE}$ valuable goals are in progress in France, such as eco-design for electrical appliances and products, recyclability, the capability of repairing and reusing (Awasthi et al. 2019). The recycling rate in France has increased from 35.3 to $42.9 \%$ between 2009 and 2017 (https:// www.citeo.com/). Based on Citeo reports, about $70.3 \%$ of MSW was recycled in 2019 which is 3.361 million tonnes, but still, $29 \%$ of plastic wastes were not recycled (Fig. 9) (https://www.citeo.com/).

The France government knows the importance of the CE in waste management, and hence a real roadmap is proposed to better management. In this roadmap, the goal is achieving $100 \%$ recycling by 2025 (Heath et al. 2020). The roadmap for a CE in France has some objectives, which should be focused on.

I. Consumption of natural resources for human needs should be decreased to $30 \%$ in 2030 , in comparison with the GPD in 2010.

II. Landfills should be emptied of non-hazardous waste to $50 \%$ by 2050 , comparing to 2010 .

III. $100 \%$ of plastics should be recycled by 2050 .

IV. Preventing GHE from plastic recycling.

V. Creating 300,000 additional jobs in the way to developing a CE.

The France CE framework is fully described in Fig. 10.
Fig. 8 The body of CE by the French parliament

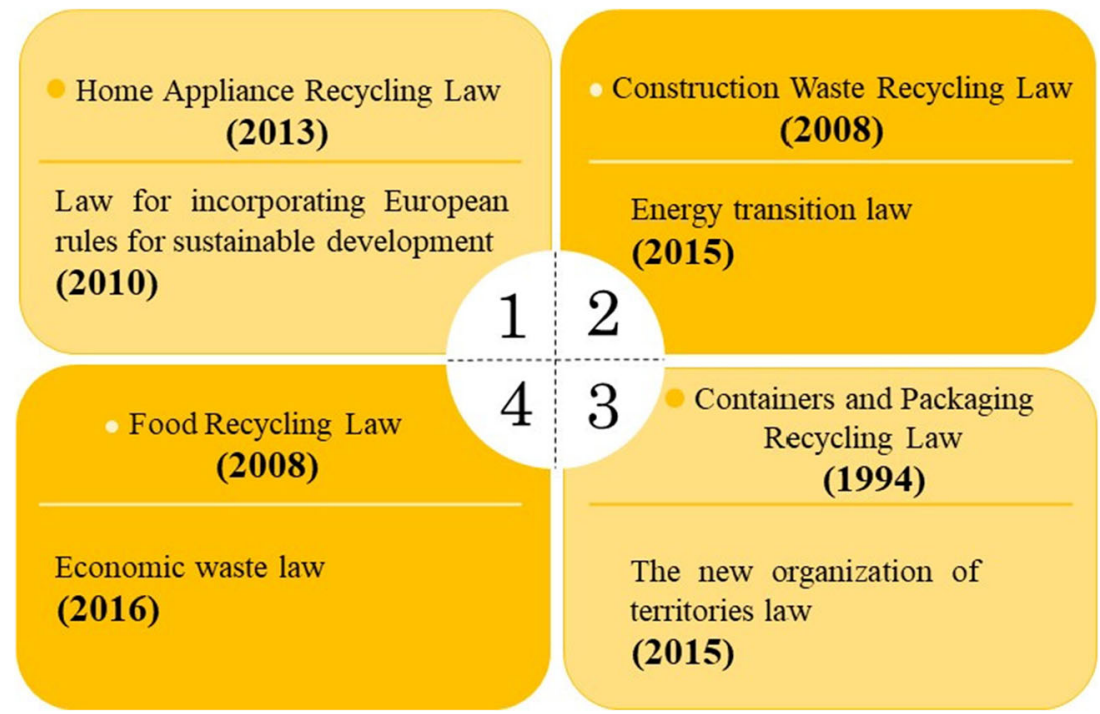




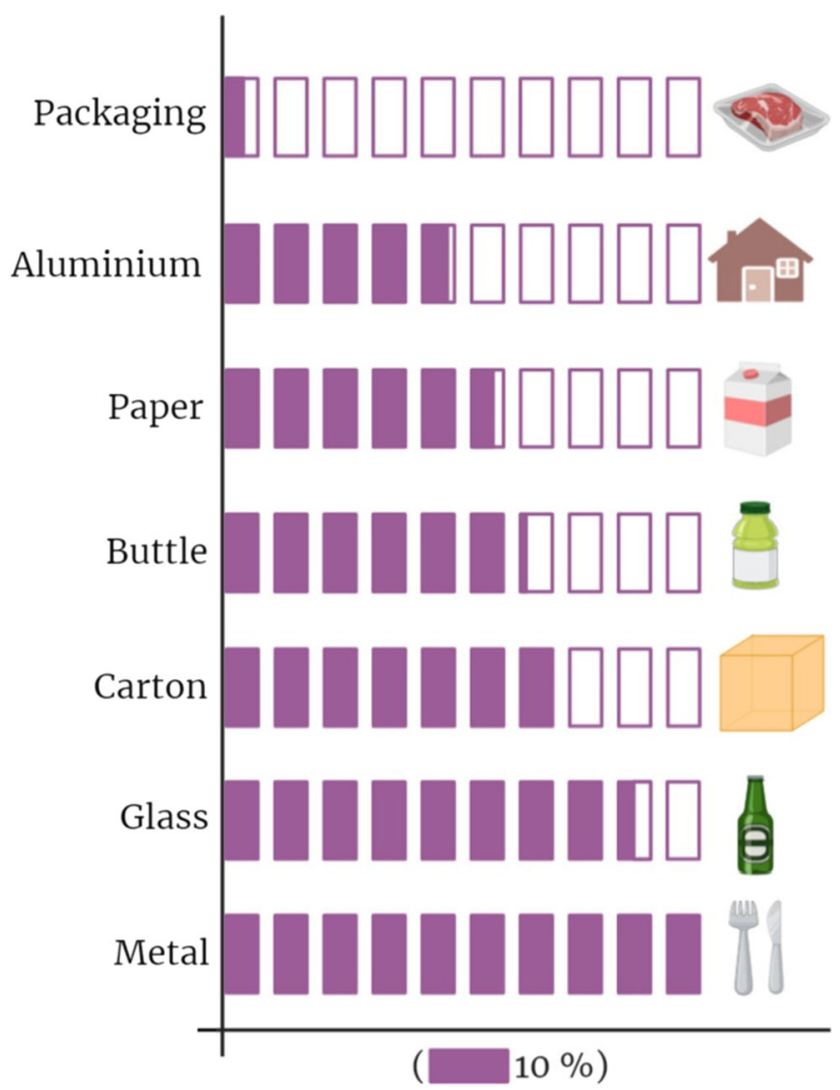

Fig. 9 The recycling rate of different materials in France in 2019

\section{Challenges and Strategies for Achieving CE Goals}

Our way to a fully zero waste masterplan is very long to go, but it needs a strong start. In transition toward a CE rather than linear economy, we face numerous challenges. Some of these challenges are climate change, rising consumption because of the global population growth, rapid urbanization and development of cities, and insufficient space for landfills. By studying the Singapore and France cases, we found out that both have opportunities to develop a CE through their growing ambitions and initiatives toward sustainable development. In Table 1, both countries are evaluated based on the CCAF (Circular City Analysis Framework) indicators in 2019. Based on the given data about the energy consumption in France and Singapore, using renewable energy in France has by far higher records. Also, electricity production in France is 584 (TW); however, this is 13,667 (MW) in Singapore. In the economic factor, France has more progression because of the high rate of GDP. There is not any budget for implementing a circular economy in Singapore; however, in France, roughly $9000 €$ is considered for CE plans. Using public transportation in France is 327 times more than in Singapore. In the waste management dimension, the incineration record is approximately similar in both countries but, the recycling rate in France is by far more than Singapore. Although, landfilling in France is negligible in comparison with Singapore, which is about 3 million. The records in other dimensions such as water management, education, and technology are high in both countries. In the social sector, there are contrasting pieces of information.

For overcoming the challenges and facilitate CE development at a micro-level, a circular hub can be established. This physical location can enable startups and concepts for inventing new technologies for making a CE. Another strategy is conducting more research experiments in the CE approach for main aspects including food, energy, mobility, housing and infrastructure, water, consumer goods, plastics, and industrial parks (Jackson 2018). These researches can make a model for other cities to achieve sustainable

Fig. 10 France roadmap for a CE

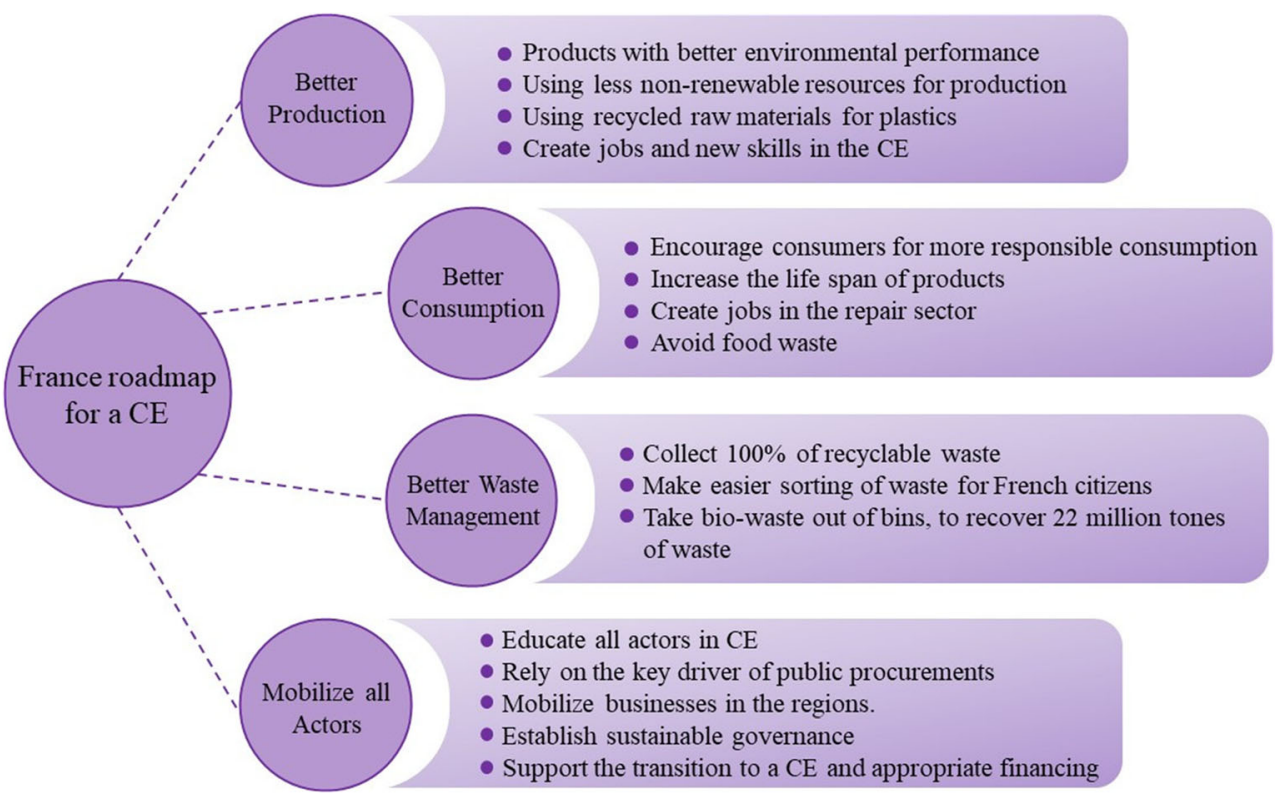


Table 1 CE criteria in Singapore and France

\begin{tabular}{|c|c|c|c|}
\hline $\mathrm{CE}$ criterion & Subcategory & Singapore & France \\
\hline \multirow[t]{7}{*}{ Energy $^{1,2}$} & Non-renewable energy & $13,364(\mathrm{MW})$ & $82,888(\mathrm{MW})$ \\
\hline & Wind power & 0 (MW) & $16,260(\mathrm{MW})$ \\
\hline & Solar energy & 255 (MW) & $10,571(\mathrm{MW})$ \\
\hline & Marine/Hydro & 0 (MW) & 24,304 (MW) \\
\hline & Bioenergy & 211 (MW) & $1776(\mathrm{MW})$ \\
\hline & Nuclear energy & 0 (MW) & 63,130 (MW) \\
\hline & Electricity production & $13,667(\mathrm{MW})^{3}$ & $584(\mathrm{TW})^{4}$ \\
\hline \multirow[t]{2}{*}{ Economy } & GDP & $\$ 372.06$ million $^{5}$ & $\$ 2715.52$ million $^{6}$ \\
\hline & CE budget & 3.5 billion $\$^{7}$ & 13 billion $€^{8}$ \\
\hline Transportation & Public transportation usage & 7.54 million trips ${ }^{9}$ & 2467.8 million trips ${ }^{10}$ \\
\hline \multirow[t]{3}{*}{ Waste management } & Incineration & $37 \%$ & $34(\%)^{11}$ \\
\hline & Recycling rate & $17(\%)^{12}$ & $70.3(\%)^{11}$ \\
\hline & Wastes in landfills & 3 million Tonnes & 7382 Tonnes $^{13}$ \\
\hline Water management & Access to safe water & $100(\%)^{14}$ & $98(\%)^{1}$ \\
\hline Education & Literacy rate & $97.5(\%)^{15}$ & $99.0(\%)^{16}$ \\
\hline Technology & Accessibility to smart phones & $83.71(\%)^{17}$ & $79.8 \% \%^{18}$ \\
\hline \multirow[t]{3}{*}{ Society } & Equality of men and women in policy & $23(\%)^{19}$ & $74.6(\%)^{20}$ \\
\hline & Heaviest age group & $45-49^{21}$ & $15-64^{22}$ \\
\hline & Active population & 3549 (thousand persons) ${ }^{23}$ & 30,394 (thousand persons) ${ }^{24}$ \\
\hline
\end{tabular}

${ }^{1} \mathrm{https}$ //www.irena.org/IRENADocuments/Statistical_Profiles/Asia/Singapore_Asia_RE_SP.pdf

${ }^{2} \mathrm{https} / / / \mathrm{www}$.irena.org/IRENADocuments/Statistical_Profiles/Europe/France_Europe_RE_SP.pdf

${ }^{3} \mathrm{https}$ ://www.siew.gov.sg/newsroom/articles/detail/2019/11/20/singapore-energy-statistics-2019

${ }^{4}$ https://www.edf.fr/sites/default/files/contrib/groupe-edf/engagements/rapports-et-indicateurs/2019/edfgroup_essentiel-2019_en.pdf

${ }^{5} \mathrm{https}: / / \mathrm{www}$. statista.com/statistics/982956/singapore-electricity-generation-capacity/

${ }^{6} \mathrm{https}: / /$ tradingeconomics.com/singapore/gdp

${ }^{7}$ https://www.singaporebudget.gov.sg/docs/default-source/budget_2019/download/pdf/fy2019_budget_in_brief_eng.pdf

${ }^{8}$ https://ec.europa.eu/info/sites/info/files/economy-finance/2019_dbp_fr_en.pdf

${ }^{9} \mathrm{https} / /$ www.statista.com/topics/5880/passenger-transport-in-singapore/

${ }^{10} \mathrm{https} / / /$ www.statista.com/statistics/612773/paris-public-transport-users-by-transit-type/

${ }^{11} \mathrm{https}: / /$ www.citeo.com/

${ }^{12} \mathrm{https} / /$ www.todayonline.com/singapore/singaporeans-generated-less-waste-2019-also-recycled-less-nea

${ }^{13} \mathrm{https} / /$ www.statista.com/statistics/994945/singapore-literacy-rate-15-years-and-older/

${ }^{14} \mathrm{https} / / /$ www.who.int/water_sanitation_health/publications/jmp-2019-full-report.pdf

${ }^{15} \mathrm{http} \mathrm{s}$ ://www.statista.com/statistics/994945/singapore-literacy-rate-15-years-and-older/

${ }^{16} \mathrm{https}$ ://stats.oecd.org/Index.aspx?DataSetCode=MUNW

${ }^{17} \mathrm{https}: / /$ www.macrotrends.net/

${ }^{18} \mathrm{https}: / / w w w . s t a t i s t a . c o m / s t a t i s t i c s / 974996 /$ singapore-mobile-phone-internet-user-penetration/

${ }^{19} \mathrm{https}: / /$ www.statista.com/topics/5707/smartphone-users-in-france/

${ }^{20} \mathrm{https}: / /$ data.unwomen.org/country/singapore

${ }^{21} \mathrm{https}$ ://data.worldbank.org/indicator/

${ }^{22} \mathrm{https}: / /$ www.statista.com/

${ }^{23} \mathrm{https}$ ://www.statista.com/statistics/624913/singapore-population-by-age-group/

${ }^{24} \mathrm{https}: / /$ www.statista.com/statistics/270347/age-distribution-in-france/

development goals. In addition, the efforts of the government by setting incentives and grants toward a CE program is inevitable. Furthermore, there was an attempt to build new resiliences, climate resilience, resource resilience to addressing the status of resources, and economic stability for granting the plans. There is an urgent need for waste recycling as the recycled materials can be used as the resources for production in factories, not from the scratch. 
One of the most promising methods for building a $\mathrm{CE}$ is setting ambitious targets as mentioned above for both France and Singapore. Moreover, we need to produce more efficient and re-engineered products with fewer materials and energies. By setting strict boundaries for the consumption of resources, a national consciousness toward environmental care can be built. Moreover, France practices toward a CE are worth mentioning; Green public procurement (GPP) encourages customers to the green purchasing behavior, which is less damaging to the environment (Lăzăroiu et al. 2020). The zero waste masterplan is beneficial for both consumers and producers. A citizen workgroup for improvement in household recycling in Singapore (Franco-García et al. 2019) and developing an eco-industrial park in France (Belaud et al. 2019) are some of these plans.

One important fact is that we should start waste management from ourselves, this behavior should be taught in schools, universities, and through the media to all generations of a society. Furthermore, we cannot tackle the waste problem, unless we manage our waste and used materials. Some of our efforts as a community to deal with waste management is listed below:

- Separating our waste from the beginning

- Donate or sell our old clothes to other people and charities

- Print on two sides of the paper and try to have software documents rather than paper files

- Order foods according to your appetite

- Buy foods daily

- Order fewer takeaway foods

- Try to use a paper bag instead of plastic bags

- Buy products with less packaging

- Use your glass for drinking instead of plastic cups and glasses

- Use less water for hygiene (for example in the bathroom, use water in washtub instead of shower)

\section{Conclusion and Future Perspective}

This article represents a case study about the waste management system, for Singapore and France along with plans for developing a $\mathrm{CE}$ in both nations. The used approach in this article is WTE. Studying the CE in Singapore and France represents that in both countries waste management has been started and planned comprehensively. The road map for a circular city is legislated in both countries which includes long-term plans. The rate of recycling in France is faster than in Singapore and it is estimated that in 2025, the recycling percent in France will reach $100 \%$, while in Singapore it is estimated to catch $70 \%$ in 2050 . Although, a transition toward a zero waste masterplan is in progress, recently due to pandemic COVID-19 some of the Resource Sustainability Bill obligations are not considered carefully. Despite the developments toward CE in Singapore, like the jet fuel program and inventing new facilities by 2022, most of the plans are in progress until 2030. In the case of France, the targets of increasing waste recycling to $100 \%$ and developing a $\mathrm{CE}$ for preventing landfilling is in progress until 2025. Furthermore, France has got through landfilling problems and this country is now encouraging customers and businesses into green purchasing and manufacturing systems to control the negative effect of waste. On the other hand, Singapore still has problems in the storage of waste materials in landfills and had not significant developments in green manufacturing.

Regarding climate change in the world and to maintain a sustainable economy in Europe, European Green Deal (EGD) was developed. The purpose of EGD is to achieve a modern and resource-efficient economy through three concrete action plans, by 2050; climate neutrality, investment bank, and sustainable investment plan. Some of the long-term incentives in this strategy include zero-emission, affordable secure energy, smarter transport, high-quality food, and better quality of life. However, in Singapore NCCS (National Climate Change Secretariat) and NDC (Nationally Determined Contribution) organizations develop plans for a sustainable economy. Moreover, some of the main goals of these organizations are as follow: introduce a carbon tax for businesses and other large carbon emitters, developing low-carbon technologies such as solar energy and other renewable sources, using power grids and solar photovoltaic systems, improving energy efficiency by motivating businesses, manufacturing electric vehicles, and introducing nuclear power plants.

There are some challenges toward building a $\mathrm{CE}$, but with some long-term strategies, the dream of becoming a CE can become into reality. As the main drivers for moving toward building a $\mathrm{CE}$, are global measures such as decoupling the economic growth, decreasing the level of emissions, and energy transition toward a sustainable supply system, it is necessary to assess the impact of national-level plans and scenarios in a global context, not just looking at a single country. While such a comprehensive qualitative analysis is still missed, the following study will provide a ground for it for future studies.

\section{Compliance with Ethical Standards}

Conflict of Interest The authors declare that they have no conflict of interest.

\section{References}

Abidin C (2020) Meme factory cultures and content pivoting in Singapore and Malaysia during COVID-19 The Harvard Kennedy School (HKS) Misinformation Review 1. https://doi.org/10.37016/ mr-2020-031 
Ademe (2016) Statistiques relatives au développement durable et à la gestion des déchets. http://www.statistiques. developpementdurable.gouv.fr/lessentiel/ar/286/0/traitementdechets.html/. Accessed 2017.07.25

Arbulú I, Lozano J, Rey-Maquieira J (2017) The challenges of tourism to waste-to-energy public-private partnerships. Renew Sust Energ Rev 72:916-921. https://doi.org/10.1016/j.rser.2017.01.036

Awasthi AK, Li J, Koh L, Ogunseitan OA (2019) Circular economy and electronic waste. Nat Electron 2:86-89. https://doi.org/10.1038/ s41928-019-0225-2

Ayodele TR, Ogunjuyigbe ASO, Alao MA (2017) Life cycle assessment of waste-to-energy (WtE) technologies for electricity generation using municipal solid waste in Nigeria. Appl Energy 201:200 218. https://doi.org/10.1016/j.apenergy.2017.05.097

Baldé CP, Forti V, Gray V, Kuehr R, Stegmann P (2017) The global ewaste monitor 2017: Quantities, flows and resources. United Nations University, International Telecommunication Union, and International Solid Waste Association. http://collections.unu.edu/ view/UNU:6341

Ballouard C, Poujol M, Boulvais P, Zeh A (2017) Crustal recycling and juvenile addition during lithospheric wrenching: the PontivyRostrenen magmatic complex, Armorican Massif (France), Variscan belt. Gondwana Res 49:222-247. https://doi.org/10.1016/ j.gr.2017.06.002

Belaud J-P, Adoue C, Vialle C, Chorro A, Sablayrolles C (2019) A circular economy and industrial ecology toolbox for developing an eco-industrial park: perspectives from French policy. Clean Techn Environ Policy 21:967-985

Carrière S, Weigend Rodríguez R, Pey $\mathrm{P}$, Pomponi F, Ramakrishna S (2020) Circular cities: the case of Singapore. Built Environ Proj Asset Manag 10(4):491-507. https://doi.org/10.1108/BEPAM-122019-0137

Chan JKH (2016) The ethics of working with wicked urban waste problems: the case of Singapore's Semakau Landfill. Landsc Urban Plan 154:123-131. https://doi.org/10.1016/j.landurbplan.2016.03.017

de Sousa Jabbour ABL, Jabbour CJC, Filho MG, Roubaud D (2018) Industry 4.0 and the circular economy: a proposed research agenda and original roadmap for sustainable operations. Ann Oper Res 270: 273-286

Deborah OM, Chiu MY, Cao K (2018) Geographical accessibility of community health assist scheme general practitioners for the elderly population in Singapore: a case study on the elderly living in housing development board flats. Int J Environ Res Public Health 15. https://doi.org/10.3390/ijerph15091988

Domenech T, Bahn-Walkowiak B (2019) Transition towards a resource efficient circular economy in Europe: policy lessons from the EU and the member states. Ecol Econ 155:7-19

Dong J, Tang Y, Nzihou A, Chi Y, Weiss-Hortala E, Ni M, Zhou Z (2018) Comparison of waste-to-energy technologies of gasification and incineration using life cycle assessment: case studies in Finland, France and China. J Clean Prod 203:287-300

Du L, Feng Y, Lu W, Kong L, Yang Z (2020) Evolutionary game analysis of stakeholders' decision-making behaviours in construction and demolition waste management. Environ Impact Assess Rev 84:106408. https://doi.org/10.1016/j.eiar.2020.106408

Franco-García M-L, Carpio-Aguilar JC, Bressers H (2019) Towards zero waste, circular economy boost: waste to resources. In: FrancoGarcía ML, Carpio-Aguilar J, Bressers H (eds) Towards zero waste. Greening of Industry networks studies, vol 6. Springer, Cham. https://doi.org/10.1007/978-3-319-92931-6_1

Fujii T, Rohan R (2019) Singapore as a sustainable city: past, present and the future SMU. Research Collection School Of Economics 170. https://ink.library.smu.edu.sg/soe research/2297

Geng Y, Jia F, Sarkis J, Xue B (2012) Towards a national circular economy indicator system in China: an evaluation and critical analysis. J Clean Prod 23:216-224
Gómez-Cortés P, Frutos P, Mantecón AR, Juárez M, de la Fuente MA, Hervás G (2009) Effect of supplementation of grazing dairy ewes with a cereal concentrate on animal performance and milk fatty acid profile1. J Dairy Sci 92:3964-3972. https://doi.org/10.3168/jds. 2009-2044

Hannon J, Zaman AU (2018) Exploring the phenomenon of zero waste and future cities. Urban Sci 2. https://doi.org/10.3390/ urbansci2030090

Heath GA et al (2020) Research and development priorities for silicon photovoltaic module recycling to support a circular economy. Nat Energy 5:502-510. https://doi.org/10.1038/s41560-020-0645-2

Heidrich O et al (2016) National climate policies across Europe and their impacts on cities strategies. J Environ Manag 168:36-45 https:// www.citeo.com/. Accessed 13 Dec 2015.

Hugo MB (1992) LOI no 92-646 du 13 juillet 1992 relative à l'élimination des déchets ainsi qu'aux installations classées pour la protection de l'environnement 417:1-197. http://pascal-francis.inist.fr/vibad/ index.php?action $=$ getRecordDetail\&idt $=6436430$

Invernizzi DC, Locatelli G, Velenturf A, Love PE, Purnell P, Brookes NJ (2020) Developing policies for the end-of-life of energy infrastructure: coming to terms with the challenges of decommissioning. Energy Policy 144:111677

Jackson P (2018) Introduction: second-generation security sector reform. J Interv Statebuilding 12:1-10. https://doi.org/10.1080/17502977. 2018.1426384

Jahani A, Dehdari T, Farzadkia M, Mansourian M (2019) Iranian experiences in terms of consumption of disposable single- use plastics: introduction to theoretical variables for developing environmental health promotion efforts. Environ Toxicol Pharmacol 65:18-22. https://doi.org/10.1016/j.etap.2018.11.004

Kerdlap P, Low JSC, Ramakrishna S (2019) Zero waste manufacturing: a framework and review of technology, research, and implementation barriers for enabling a circular economy transition in Singapore. Resour Conserv Recycl 151:104438. https://doi.org/10.1016/j. resconrec.2019.104438

Kuznetsova E, Cardin M-A, Diao M, Zhang S (2019) Integrated decisionsupport methodology for combined centralized-decentralized wasteto-energy management systems design. Renew Sust Energ Rev 103: 477-500. https://doi.org/10.1016/j.rser.2018.12.020

Lahsen M, de Azevedo Couto G, Lorenzoni I (2020) When climate change is not blamed: the politics of disaster attribution in international perspective. Clim Chang 158:213-233

Lăzăroiu G, Ionescu L, Uță C, Hurloiu I, Andronie M, Dijmărescu I (2020) Environmentally responsible behavior and sustainability policy adoption in green public procurement. Sustainability 12. https:// doi.org/10.3390/su12052110

Liszka D, Walawender P (2018) Neet youth-the concept's presence in the european union's youth employment policy and why it is so problematic. Humanities and Social Sciences 179-193. https://doi.org/ 10.7862/rz.2018.hss.77

Liu Z, Adams M, Walker TR (2018) Are exports of recyclables from developed to developing countries waste pollution transfer or part of the global circular economy? Resour Conserv Recycl 136:22-23

MacArthur E (2013) Towards the circular economy, economic and business rationale for an accelerated transition. Ellen MacArthur Foundation, Cowes, pp 21-34

Malinauskaite J, Jouhara H, Czajczyńska D, Stanchev P, Katsou E, Rostkowski P, Thorne RJ et al (2017) Municipal solid waste management and waste-to-energy in the context of a circular economy and energy recycling in Europe. Energy Policy 141:2013-2044

Mawhood R, Gazis E, de Jong S, Hoefnagels R, Slade R (2016) Production pathways for renewable jet fuel: a review of commercialization status and future prospects. Biofuels Bioprod Biorefin $10: 462-484$ 
Nguyen TVH (2019) Circular economy and waste recycling-review, challenges and opportunities in Vietnam and France. http:// tailieuso.tlu.edu.vn/handle/DHTL/9026

Pagés-Díaz J, Pereda-Reyes I, Taherzadeh MJ, Sárvári-Horváth I, Lundin M (2014) Anaerobic co-digestion of solid slaughterhouse wastes with agro-residues: synergistic and antagonistic interactions determined in batch digestion assays. Chem Eng J 245:89-98

Pan S-Y, Du MA, Huang I-T, Liu I-H, Chang E, Chiang P-C (2015) Strategies on implementation of waste-to-energy (WTE) supply chain for circular economy system: a review. J Clean Prod 108: 409-421

Pavlas M, Touš M, Klimek P, Bébar L (2011) Waste incineration with production of clean and reliable energy. Clean Techn Environ Policy 13:595-605

Qu S et al (2019) Implications of China's foreign waste ban on the global circular economy. Resour Conserv Recycl 144:252-255. https://doi. org/10.1016/j.resconrec.2019.01.004

Rezvani Ghomi E, Esmaeely Neisiany R, Nouri Khorasani S, Dinari M, Ataei S, Koochaki MS, Ramakrishna S (2020a) Development of an epoxy self-healing coating through the incorporation of acrylic acidco-acrylamide copolymeric gel. Prog Org Coat 149:105948. https:// doi.org/10.1016/j.porgcoat.2020.105948

Rezvani Ghomi E et al (2020b) The flame retardancy of polyethylene composites: from fundamental concepts to nanocomposites. Molecules 25. https://doi.org/10.3390/molecules25215157

Shanmugam V et al (2020) Polymer recycling in additive manufacturing: an opportunity for the circular economy. Materi Circ Econ 2:11. https://doi.org/10.1007/s42824-020-00012-0
Sharma HB et al (2020) Challenges, opportunities, and innovations for effective solid waste management during and post COVID-19 pandemic. Resour Conserv Recycl 162:105052

Siow LG, Lee Charles CC (2020) Singapore's 2030 Zero waste masterplan (ZMP): is it achievable? Proceedings of the International Conference on Environmental Science and Applications (ICESA'20). https://doi.org/10.11159/icesa20.125

Steele S, Ramsay I, Webster M (2019) Insolvency law reform in Australia and Singapore: directors' liability for insolvent trading and wrongful trading. Int Insolv Rev 28:363-391. https://doi.org/10.1002/iir.1349

Telega I, Telega A (2020) Driving factors of material consumption in European countries - spatial panel data analysis. J Environ Econ Policy 9:269-280. https://doi.org/10.1080/21606544.2019.1675186

Tukker A (2015) Product services for a resource-efficient and circular economy-a review. J Clean Prod 97:76-91

Van Rensburg ML, Nkomo SL, Dube T (2020) The 'plastic waste era'; social perceptions towards single-use plastic consumption and impacts on the marine environment in Durban, South Africa. Appl Geogr 114:102132. https://doi.org/10.1016/j.apgeog.2019.102132

Woodard R (2021) Waste Management in Small and Medium Enterprises (SMEs): compliance with duty of care and implications for the circular economy. J Clean Prod 278:123770. https://doi.org/10.1016/j. jclepro.2020.123770

ZERO WASTE MASTERPLAN (2020) Towardszerowaste.gov.sg. Available from: https://www.towardszerowaste.gov.sg/zerowastemasterplan/. Accessed 5 Aug 2020 